\title{
Rudolf Bultmann se ontmitologisering van die Nuwe-Testamentiese eskatologie
}

\author{
GMM Pelser \\ Instituut vir Teologiese Navorsing \\ Universiteit van Suid-Arika
}

\begin{abstract}
Rudolf Bultmann's demythologizing of the eschatology of the New Testament

This article investigates Bultmann's views on the eschatology of the New Testament as expressed respectively by Jesus, the earliest Christians, Paul, John and the churches of the post-apostolic period. It also pays attention to what Bultmann has to say about the secularisation of eschatology during the history of the church, and about the relationship history-eschatology. The conclusion is that although his program of demythologizing has far-reaching and dire consequences for the traditional end-time eschatological expectations of the church, much of it is to be evaluated positively. Much is also to be gained from his insights especially with regard to his emphasis on the existential importance of the decision of faith, in the moment here and now, for authentic existence as the eschatological event.
\end{abstract}

\section{DIE MITOLOGIESE KARAKTER VAN DIE NUWE-TESTAMENTIESE ESKATOLOGIE EN DIE NOODSAAK VIR ONTMTTOLOGISERING}

Wie reeds kennis geneem het van Bultmann se veelgediskusseerde ontmitologiseringsprogram sal weet dat 'n baie belangrike komponent daarvan uitgemaak word deur sy ontmitologisering van die eskatologie van die Nuwe Testament. Soos hy

Hierdie studie is voorberei as deel van 'n navorsingsprojek van die Instituut vir Teologiese Navorsing aan die Universiteit van Suid-Afrika. 
naamlik die Nuwe-Testamentiese voorstellings en uitsprake oor God, oor die handelinge van God en oor die Christusgebeure as mitologies beskou, so beskou hy die voorstellings en uitsprake oor die toekoms as mitologies (1954a: 11; 1965a: 100). 'Wie bei der Vorstellung vom Himmel die Transzendenz Gottes durch răumliche Mittel ausgedrückt wird, so wird in der Vorstellung vom Ende der Welt die Transzendenz Gottes durch zeitliche Mittel dargestellt' (1964a: 21). Om hierdie rede is dit volgens hom vanselfsprekend en noodsaaklik dat net soos alle ander mitologiese voorstellings in die Nuwe Testament, ook die mitologiese eskatologie ontmitologiseer en eksistensiaal interpreteer moet word.

Hoewel daar nie in hierdie opstel gehandel sal word oor Bultmann se ontmitologiseringsprogram as sodanig nie (kyk o a Pelser 1987), is dit nogtans nodig om daarop te wys dat met betrekking tot die ontmitologisering van die eskatologie, dieselfde redes aangevoer word as wat vir die ontmitologisering van die NuweTestamentiese mitologie in die algemeen geld. Hierdie redes is die volgende: (a) die wêreldbeeld van die moderne wetenskaplik georiënteerde mens het só verander dat hy hom nie meer kan vereenselwig met die wêreldbeeld van die Nuwe Testament nie; (b) die intensie van die mite self is nie om 'n objektiewe wêreldbeeld aan ons op te dring nie, maar om tot uitdrukking te bring hoe die mens homself in sy wêreld verstaan, en dat dit daarom nie kosmologies nie maar antropologies, beter nog, eksistensiaal geïnterpreteer wil word; (c) deur middel van ontmitologisering moet die waarheid van die kerugma as kerugma by die nie-mitologies denkende mens tuisgebring word; (d) die Nuwe Testament stel self die vereiste vir ontmitologisering vanweë die feit dat daarin voorstellings voorkom wat mekaar weerspreek en vanweë die feit dat ontmitologisering reeds hier en daar in die Nuwe Testament self voorgekom het.

Ons vind, volgens Bultmann, twee Hoffnungsbilder in die Nuwe Testament, naamlik onderskeidelik 'n Joodse en 'n Hellenisties-gnostiese verwagting (1960c: 26). Eersgenoemde is die verwagting dat Jesus in die toekoms op die wolke sal kom en dat by sy koms hierdie wêreld katastrofies tot sy einde sal kom en die dooies sal opstaan en geoordeel sal word, sommiges om die ewige lewe te beërwe en ander om die ewige dood in te gaan. Laasgenoemde, en 'n hiervan totaal verskillende verwagting is die gedagte dat die siel van die gelowige onmiddellik na die dood na die hemel sal opvaar, terwyl die wêreld sal vergaan (1960a: 81-83). In eersgenoemde geval kom die heil na die aarde toe en word die aarde verander tot ' $n$ plek van saligheid. In laasgenoemde vind die ondergang van die wêreld plaas en word die siel gered om in die heerlikheid van die ligwêreld te deel.

Beide hierdie voorstellings is mitologies omdat beide enersyds die goddelike wêreld van heil en lig voorstel as 'n werklikheid binne die kosmiese ruimte bo ons 
aarde en andersyds die einde van die wêreld nie verwag as die gevolg van natuurlike oorsake nie maar van die ingryping van bonatuurlike magte (1960a: 83-84). Elkeen van hierdie voorstellings is ook met sy eie beskouing oor die verloop van die geskiedenis verbind. Eersgenoemde sien Israel se geskiedenis as 'n deur God bepaalde heilsgeskiedenis, en daarmee saam die geskiedenis van die ander volke as opeenvolgende epogge. Laasgenoemde dink egter nie oor die verloop van die wêreldgebeure in historiese nie, maar in kosmologiese kategorieë. Die wêreldgeskiedenis word hier gesien as 'n proses wat begin het met die vermenging van ligelemente met die duisternis, en voortgesit word in die bevryding van hierdie ligelemente deur die hemelverlosser wat vir dié doel na die aarde neergedaal het.

Vanweë die mitologiese aard van albei hierdie Hoffnungsbilder sê Bultmann onder andere van die eerste: 'Wir können die Vorstellung vom Kommen Christi auf den Wolken des Himmels ehrlicherweise nicht mehr vollziehen ... und wenn wir mit einem Ende der Welt rechnen, so doch nur mit einem durch Naturprozesse bzw. Naturkatastrophen herbeigeführten Ende' (1960a: 84). En van die laaste: 'Auch das ist eine für den modernen Menschen vergangene und nicht mehr nachfollziehbare Vorstellung ...' (1960a: 85).

By die eerste kennismaking met die feit dat Bultmann ook die Nuwe-Testamentiese eskatologie ontmitologiseer het, mag 'n mens die indruk kry dat hy inderdaad die begrip 'eskatologies' wou uitsuiwer. Dit is egter verre daarvandaan. By die lees van sy geskrifte word dit naamlik gou duidelik hoe dikwels die term 'eskatologies' daarin voorkom en watter belangrike en inderdaad sentrale rol dit in sy teologie speel. Körner (1957: 13) het daarom die saak reg opgesom toe hy gesê het: 'Seinem Theologiebegriff entsprechend rückt so das Eschatologische an die zentrale Stelle des theologischen Aufrisses und wird zum Prinzip theologischen Denkens überhaupt'.

Om in meer besonderhede ' $n$ indruk te kry van Bultmann se beskouings oor hoe daar in die Nuwe Testament met die eskatologie te werk gegaan is, is dit nodig om te kyk na wat hy te sê het oor die belangrikste getuienisse of eksponente van die eskatologie in die Nuwe Testament, asmede die ontwikkelings wat hy meen daar by die onderskeie eksponente plaasgevind het.

\section{BULTMANN SE EVALUERING VAN DIE BELANGRIKSTE NUWE-TESTA- MENTIESE EKSPONENTE VAN DIE ESKATOLOGIESE VERWAGTING}

Jesus

Daar is by Bultmann geen twyfel dat Jesus se toekomsverwagting mitologies was nie. 
Sy verkondiging was beheers deur die gedagte van die onmiddellik voor die deur staande Godsheerskappy, en hiermee het $\mathrm{Hy}$ in historiese samehang gestaan met die Joodse eind- en toekomsverwagting, hoewel Hy nie die nasionale verwagting wat hieraan verbonde was, verteenwoordig het nie. Hy het eerder die kosmologiese verwagting van die apokaliptiek gedeel, maar Hom weerhou van die fantastiese spekulasies van die apokaliptiek en van die berekening van tydsverloop of die uitwys van tekens waaraan die aanbreek van die einde bespeur sou kon word. Hy het Hom eweneens weerhou van beskrywings van die gerig, die opstanding en die ewige heerlikheid. Alles word by Hom oorheers deur die één gedagte, naamlik dat God (dan) sal heers. Hy was vas van oortuiging dat die huidige wêreldtyd afgeloop was, en in die lig van die nabyheid van die toekoms het die hede vir Hom die tyd van beslissing geword. As eindfiguur wat al hierdie dinge aan die gang sou sit, het $\mathrm{Hy}$ die Menseseun uit die hemel as regter en verlosser verwag. En die saligheid van die geregverdigdes word deur Hom met die eenvoudige aanduiding 'lewe' beskryf (1949: 97; 1960b: 96).

Wat egter belangrik is, is Jesus se oortuiging: 'Jetzt ist die Zeit gekommen! die Gottesherrschaft bricht herein! die Zeit des Endes ist da!' (1949: 97). In die lig hiervan is dit nou die tyd van beslissing en is Jesus se prediking die oproep tot beslissing. Hierdie beslissing moet radikaal gemaak word, dit wil sê dit is 'n beslissing of vir God of vir die wêreld. As beslissing vir God behels dit die afstand doen van die dinge wat ' $n$ mens aan die wêreld bind. Hierdie prysgawe van die dinge van die wêreld is egter geen wêreldontvlugting nie, geen askese nie, maar daardie Entweltlichung wat niks anders is nie as die gereedheid vir God se eis wat uit alle wêreldse bindinge wegroep. Positief stem dit ooreen met die eis van die liefde waarin die mens hom van homself afwend om vir die ontmoeting met die naaste oop te wees. En deurdat hy vir die naaste dár is, het hy hom vir God bereid verklaar.

Daar bestaan volgens Bultmann geen twyfel daaroor dat Jesus se verwagting van die nabye einde van die wèreld 'n vergissing was nie. Die vraag is egter nou of die betekenis van Jesus se prediking aan hierdie vergissing gebonde is. Hierop antwoord Bultmann: 'Man kann vielmehr sagen, dass diese Erwartung die Folge des Grundgedankens seiner Verkündiging ist' (1949: 102). Maar wat was nou die grondgedagte van Jesus se verkondiging en waarom het hierdie grondgedagte gelei tot sy nabye verwagting? Hiervoor is daar 'n goeie verklaring. Profetiese bewussyn verwag altyd God se gerig in die onmiddellikste toekoms. Die oortuiging dat die houding van die mens voor God beslissend vir sy lot is en dat die tyd vir beslissing beperk is, klee homself in die voorstelling dat die uur van beslissing vir die wèreld aangebreek het. So was dit ook die geval by Jesus. Die bewussyn om die beslissende wil van God te ken en te moet verkondig, het Hom die bewussyn gegee van 
aan die einde van die tyd te staan. Sy eskatologiese prediking het nie uit 'n bepaalde verlange of op grond van eie spekulasie ontstaan nie, maar uit die wete om die nietigheid van die wêreld, om die wil van God en om die verantwoordelikheid van die mens voor God. Die hiermee gegewe verstaan van die menslike eksistensie is duidelik nie aan die verwagting van die nabye einde van die wèreld gebonde nie, maar bevat ' $n$ bepaalde oordeel oor die wêreld, dit wil sê dit sien die wêreld gewoonweg sub specie Dei (1949: 102-103). Al het Jesus Hom dus wat betref die einde van die wêreld en die nabyheid van hierdie einde vergis, kan die betekenis van sy mitologiese prediking, eksistensiaal geïnterpreteer, nogtans soos volg saamgevat word: Oop wees vir God se toekoms wat voor elkeen van ons staan; gereed wees vir hierdie toekoms wat soos 'n dief in die nag kan kom wannneer ons dit nie verwag nie; gereed wees, want hierdie toekoms sal 'n gerig wees oor alle mense wat hulleself aan hierdie wêreld verbind het en nie vry is nie, nie oop is vir God se toekoms nie (1964a: 32-33).

Wat Bultmann duidelik hiermee wil sê, is dat Jesus se nabye verwagting, geontmitologiseer en eksistensiaal geînterpreteer, nie 'n struikelblok hoef te wees nie. Sy verkondiging was dus nie só gebonde aan sy nabye verwagting dat die essensiële en daarom eksistensiale betekenis van sy verkondiging daardeur tot niet gemaak word nie - al het Jesus Hom oor die nabyheid van die eskatologiese gebeure vergis en dit op mitologiese wyse as kosmiese gebeure voorgestel.

\section{Die vroegste Christene}

Die vroegste Christene het hulle by die verwagting van Jesus aangesluit, Hom as die komende Menseseun verkondig en in die oortuiging geleef dat hulle reeds die eskatologiese tyd betree het. Die bewussyn om die eskatologiese gemeente te wees, het tegelyk die bewussyn ingehou om uit die huidige wêreld afgesonder te wees. Die Christen het homself nie meer gesien as iemand met 'n verantwoordelikheid teenoor die bestaande wêreld en sy ordeninge nie. Daarom is van die Christen verwag om hom rein te hou van die wêreld en eintlik daarvan af te sonder. 'Alles das bedeutet: Im Urchristentum ist die Geschichte durch die Eschatologie verschlungen worden' (1964b: 42; kyk ook 1960b: 99).

Die vraag is hoe lank hierdie opvatting kon standhou in die lig van die feit dat soos Jesus se verwagting van die nabye koms van die koninkryk nie gerealiseer het nie, die verwagte paroesie van die Menseseun ook nie plaasgevind het nie. 'Diese Hoffnung, die Jesus und die Urchristenheit teilten, wurde nicht erfüllt. Immer noch besteht dieselbe Welt, und die Geschichte geht weiter' (1964a: 11; kyk ook 1965a: 98). Wat het dan in werklikheid gebeur? Wat gebeur het, is dat die voortgang van die geskiedenis die mitologie weerlê het. En omdat die vroegste Christene nie die 
mitologiese aard van hierdie verkondiging en verwagting verstaan het nie, het die uitbly van die vervulling hiervan vir hulle probleme begin skep. Die probleem rondom die eskatologie het vir die vroegste Christene nie alleen daaruit ontstaan dat die einde van die wêreld nie aangebreek het nie, die Menseseun nie gekom het en die geskiedenis verder verloop het nie, maar ook uit die feit dat die eskatologiese gemeente hom nie daarvan kon losmaak om 'n historiese grootheid te word nie en dat die Christelike geloof homself as 'n nuwe godsdiens in die wêreld gevestig het (1964b: 44). Hoewel dit duidelik is dat die ontnugtering nie oral ewe groot was en op dieselfde tyd ingetree het nie, blyk dit nogtans dat dit beslis vir die kerk 'n probleem geword het. Dat hierdie nie-vervulling van die vroeg-kerklike verwagtings 'n probleem geword het, kan veral in twee verskynsels waargeneem word. Enersyds blyk dit uit die verskynsel van die kerklike geskiedskrywing waarmee deur die outeur van Lukas-Handelinge begin is, en andersyds uit die betekenis wat die tradisie in die kerk gekry het, reeds by Paulus maar dan veral in die na-Pauliniese briefliteratuur.

Hoe het die vroegste kerk as wêreld-histories wordende grootheid hierdie probleem probeer hanteer? Of anders gestel, hoe is die geskiedenis en die verhouding van geskiedenis en eskatologie toe verstaan? Een van die wyses waarop die saak hanteer is, is dat hoewel daar nog aan die oorspronklike verwagting vasgehou is, die termyn daarvan in die onbepaalde toekoms in vooruitgeskuif is (1960a:82). Nog 'n antwoord wat probeer is, is die van 2 Petrus, maar dit kon nie werk nie. Die oplossing het opgesluit gelê in 'n nuwe verstaan van eskatologie wat reeds by Paulus begin het en deur Johannes radikaal deurgevoer is.

\section{Paulus}

Paulus het die apokaliptiese geskiedsbeeld beslissend gemodifiseer deurdat die verlede, die geskiedenis van die mens onder die sonde en die wet, vir hom 'n positiewe betekenis met betrekking tot die toekoms gekry het. Met ander woorde hy het die geskiedsbeeld van die apokaliptiek vanuit die perspektief van sy antropologie geïnterpreteer. Die sonde wat deur middel van die wet tot sy volle maat gegroei het, het daartoe bygedra dat die genade in oorvloed en kragtig gerealiseer het (Rom 5: 20v). So het die sonde 'n positiewe betekenis gehad (1964b: 47).

Nie alleen die apokaliptiese geskiedsbeeld nie, ook die apokaliptiese eskatologie is deur Paulus gemodifiseer. Dit beteken dat hy die eskatologiese voleinding nie beskou het as die voleinding van Israel of die volkere nie. Ook sy voorstelling oor die eskatologiese heil is veel eerder deur sy antropologie bepaal (1964b: 48), en die geskiedenis van die mensheid is vir hom eintlik die geskiedenis 
van die mens. Daarom kan hy hiervoor gewoon 'ek' gebruik (Rom 7: 7-25a). Hy handhaaf wel nog die verwagting van die opstanding van die dooies, die gerig, en die heerlikheid waarmee die gelowige beloon sal word, maar die eintlike heil is vir hom die geregtigheid, en daarmee saam die vryheid (Rom 14: 17). 'Das bedeutet aber: die Vorstellung vom Heil ist am Individuum orientiert. Und dieses Heil ist auch schon Gegenwart' (1964b: 48; kyk ook 1965a: 101; en 2 Kor 5: 17; 6: 2; Gal 4: 4, 6). Die Gees as gawe is wel eerstelingsgawe en die geloof is voorlopig en sal deur sien gevolg word (Rom 8: 23; 2 Kor 1: 22; 5: 5, 7; 13:12), maar hierdie hoop geld eerstens die individu, en die blik is nie meer op die volks- of wêreldgeskiedenis gerig nie. Dit is ook nie meer 'n blik op 'n nuwe geskiedenis nie, want die geskiedenis het sy einde bereik omdat Christus die einde van die wet is (Rom 10: 4). Verder het vir die gelowige wat 'in Christus' is, die beslissende reeds gebeur. Niks kan hom meer van die liefde van God skei nie (Rom 8: 35-39; 14: 7-9). Hy is nou reeds vry en die meester van alle noodlot (1 Kor 3: 21-23).

Die geskiedenis van Israel en van die wêreld het dus uit Paulus se gesigsveld verdwyn. Nou gaan dit om die Geschichtlichkeit des menschlichen Seins (1964b: 49), dit wil sê die geskiedenis wat elke mens ervaar en kan ervaar, en waardeur hy eers sy wese verwesenlik. 'So steht das Leben des Menschen immer vor ihm, und in seinen Entscheidungen wird es zu einem verfehlten oder zu einem eigentlichen erfüllten' (1964b: 50). In sy beslissings kies hy in werklikheid nie vir hierdie of daardie nie, maar kies hy vir homself as die een wat hy eintlik moet en wil wees, of as iemand wat sy eintlike lewe verydel. Die egte historisiteit (Geschichtlichkeit) van die Christelike lewe is ook daarin geleë dat dit 'n voortdurende onderwegwees is tussen 'nie meer' en 'nog nie'. Die Christelike lewe is dus nie 'n statiese nie maar 'n dinamiese, 'n steeds nuwe oorwinning deur die krag van die Gees (Rom 8: 12v; Gal 4: 17; kyk ook Rom 6: 12-23; 1 Kor 6: 12; Gal 5: 25).

Wat Bultmann onder die dialektiese verhouding van 'nie meer' en 'nog nie' by beide Paulus en Johannes verstaan, sal later duidelik word.

\section{Johannes}

Johannes het, anders as Paulus, radikaal gebreek met die apokaliptiese toekomseskatologie (1960c: 30). Die sending van Jesus Christus is vir hom die eskatologiese gebeurtenis, en geloof in hierdie gebeurtenis gee lewe. God se liefde wil red, maar is tegelyk die oorsprong van die gerig vir die wat hierdie liefde afwys. Om God se liefde af te wys, is gerig. Alleen omdat God se gebeurteniswordende liefde daar is, is die gerig daar. 'Das Gericht ist also keine besondere Veranstaltung, die zum Kommen und Gehen des Sohnes noch hinzukommt; es ist nicht ein dramatisches kosmisches Ereignis, das noch aussteht und auf das man noch warten muss' (1968a: 
11). Die gerig vind reeds plaas in die houding wat teenoor die woorde van Jesus geopenbaar word (1968b: 391).

By Johannes is daar ook nie meer sprake van die paroesie van Jesus wat aan die einde van die tyd sal plaasvind nie. Die opstanding en paroesie van Jesus is vir hom identies (1968b: 410). Johannes verwerp dus nie die gedagte van die paroesie van Jesus nie. Die verskil met die ander (futuristiese) paroesieverwagtings is slegs dat die paroesie reeds plaasgevind het. Daar is dus nie 'n tweede koms nie. Hierdie koms wat reeds plaasgevind het, is die wending van die aione. Die vroegste kerk het in werklikheid ook nie van 'n tweede koms van Jesus gepraat nie maar slegs van sy koms (1968b: 30). Dat die paroesie vir Johannes nie 'n nog uitstaande dramatieskosmiese gebeurtenis is nie, is vanselfsprekend in die lig van die feit dat reeds die koms van Jesus die kpiors is (1968b: 411).

Vir sover daar wel futuristies van Jesus se koms sprake is, gaan dit nie om 'n wederkoms op die wolke soos dit in die paroesievoorstellings in die Sinoptiese Evangelies verwag is nie (1968b: 411) maar om sy koms in die Gees. 'Nicht anders aber als eben im Geist wird er wiederkommen; die alte urchristliche Vorstellung von seiner Parusie ist preisgegeben; die Welt wird von seiner Wiederkommen nichts wahrnehmen' (Joh 14: 21v; 1968b: 437). Hy kom as parakleet. Maar met parakleet word nòg 'n nuwe ontwikkelingstadium van die dogmengeskiedenis bedoel, nòg 'n 'innerlike lig' of so iets. Die parakleet is die ander helper, soos Jesus die eerste was. Dit is egter Jesus self wat as parakleet na sy gemeente toe kom, en hierdie koms is sy koms in die Woordverkondiging. Die belofte van die parakleet is niks anders nie as die belofte 'dass die Offenbarung in der Wortverkündigung der Gemeinde sich fortsetzen wird; sein 'Zeugnis-ablegen' ist das autorisierte 'Zeugnis-ablegen' der Gemeinde' (Joh 15: 26v; 1964c: 147; kyk ook 1968b: 442). Om dit nog meer toegespits te sê, die parakleet 'ist das in der Gemeinde gepredigte Wort' (1964c: 146). So vind die paroesie van Jesus telkens weer in die Woordverkondiging plaas, kom Hy en kom Hy altyd weer in die Woordverkondiging.

Van die eskatologiese drama aan die einde van die tyd, wat in hoop of angs verwag is, is daar by Johannes eweneens nie meer sprake nie. So is Johannes 5: 2427 dan ook in aansluiting by 3: 19 'n korreksie op die ou verwagting: die eskatologiese gedagte het sy waarheid in dit wat nou voltrek word.

Für Johannes ist die Totenauferstehung und das Gericht Gegenwart geworden mit dem kommen Jesu (1964b: 53; Joh 3: 18-19, 36; 5: 2425; vgl 11: 23-26). 
Mag nun kommen, was da will, an kosmischen Katastrophen, - das kann nie etwas anderes sein, als was alle Tage in der Welt passiert. Mag nun noch etwas kommen wie eine Auferstehung aus den Gräbern (Joh 5: 28f), - das kan nichts anderes mehr sein, als wie man jeden Morgen vom Schlaf erwacht. Die Stunde ist da, da die Toten die Stimme des Gottessohnes hören; und wer sie hört, der ist vom Tode zum Leben hinübergeschritten (Joh 5, 24f) (1964c: 144-145; vgl 1968a: 193).

Dit hou in dat die begrippe wat die ou eskatologie beheers het, naamlik dat die dood die vernietiging van die aardse lewe in die sterwe is en dat die verwagte eskatologiese 'lewe' die onsterflikheid is wat in die herroeping (Rückgängig. machung) van die sterwe geskenk word, opgehef is (1968b: 193-194). Wat Jesus aan die gelowige (hoorder) as lewe beloof, is 'jene Eigentlichkeit der Existenz, die in der Erleuchtung des definitiven sichverstehens geschenkt wird' (1968a: 194). En dit leer die gelowige dat hy om hierdie eintlikheid te vind, hom van die gebruiklike begrippe van dood en lewe moet afwend en moet weet dat die lewe slegs geskenk word in die geloof aan die Openbaarder, aangesien in Hom God ontmoet en geken word. Die eskatologiese nou is die teenwoordigheid van die openbaringswoord (Joh 5: 25). Net so word in Johannes 4: 23 die 'komende' eskatologiese oomblik wat aan die einde van die tyd verwag is, as die teenwoordige verklaar waarin die woord van die Openbaarder weerklink; dit is die uur van die opstanding van die dooies (1968a: 194). Dit beteken dat vir wie nog in hierdie lewe is, maar ' $n$ gelowige is, daar nie meer so iets as die dood in finale sin bestaan nie. Die sterwe as diepste verskrikking het vir hierdie mens wesenloos geword. Trouens ook die lewe in menslike sin, het vir hom wesenloos geword, want hy staan, in soverre hy die Openbaarder gelowig sien, voor God self. Die geloof laat vaar hom dus ook die lewe as die 'hoogste goed', (1968a: 308).

Maar wat hou dit alles in om gelowige te wees? Geloof is wegkering van die wèreld, ontwêreldliking (Entweltlichung), prysgawe van skynsekerheid en lewensleuens, en die bereidheid om te lewe uit wat onsigbaar is en waaroor ' $n$ mens nie kan beskik nie (Unverfügbaren). Dit is om volledig nuwe maatstawwe aan te neem met betrekking tot dit wat dood en lewe genoem word, en die lewe te ontvang wat Jesus gee en is (Joh 5: 19vv; 11:25v) en wat in die wêreld nie aanwysbaar is nie. Geloof is die oorwinning oor die ergernis (Anstoss) dat 'n mens die lewe slegs in die Woord ontmoet wat deur'n blote mens, Jesus van Nasaret, aan jou gerig word - 'n mens wat daarop aanspraak maak dat God in Hom te ontmoet is, sonder dat Hy hierdie aanspraak vir die wêreld geloofwaardig kan maak (1968b: 428). As oorwin- 
ning oor hierdie ergernis en die beslissing teen die wêreld is geloof egter nie wêreldontvlugting en askese nie maar Entweltlichung. Enersyds hou hierdie Entweltlichung die 'Zerbrechung aller menschlichen Masstäbe und Wertungen' (1968b: 428) in en andersyds die Übergang in die eschatologische Existenz (1968b: 430). Dit beteken dat die gelowige hoewel hy nog in die wêreld is, reeds aan die wêreldlike syn ontneem is. Hy is nie meer van die wêreld nie en sy lewe is nie meer 'n funksie van die wêreldgeskiedenis nie (1964b: 56-57). Hy het reeds deur die gerig gegaan en in die lewe oorgegaan (Joh 3: 18; 5: 24v), hy het die dood reeds agter hom gebring (Joh 8: 51; 11: 25v), hy het reeds die lewe (Joh 3: 16; 6: 47; 1 Joh 5: 12) (1968b: 430).

Soos vir Paulus, is ook vir Johannes die syn van die gelowige nie 'n statiese toestand nie maar' $n$ beweegdheid van die historiese lewe in die dialektiek van indikatief en imperatief. Wat die gelowige is, dit moet hy word, en wat hy moet word, dit is hy reeds in die vryheid waartoe hy deur die geloof bevry is, 'n vryheid wat hom in gehoorsaamheid manifesteer (vgl Joh 15: 2-4) (1964b: 55).

Ook Johannes sien vooruit na die toekomstige voleinding van die huidige geloofslewe. Hy verstaan dit egter nie soos Paulus in die sin van die apokaliptiese eskatologie nie. Die uitsig op die toekoms het veel meer betrekking op die toekoms van die individuele gelowige aan die einde van sy aardse lewe. En in hierdie opsig maak Johannes gebruik van die voorstellingswyse van die gnostiese eskatologie wat die onmiddellike vereniging van die siel met die godheid verwag het (1964b: 56).

Vir beide Paulus en Johannes is die huidige tyd 'n tussentyd tussen die koms van Christus en die voleinding. Vir Paulus val die voleinding egter saam met die einde van die wêreld, terwyl dit vir Johannes die einde van die aardse lewe van die gelowige is. Vir beide is dit egter belangrik dat hierdie tussentyd nie net kronologies bepaald is nie maar dat dit die syn van die gelowige saaklik karakteriseer, naamlik as die dialektiese syn van 'nie meer' en 'nog nie'. 'Die Glaubenden sind schon der Welt entnommen, und ihr Sein ist ein eschatologisches Sein, und doch leben sie noch in der Welt, "und es ist noch nicht offenbar, was wir sein werden" (1 Joh 3: 2) (1964b: 56-57; vgl 1965b: 205).

In soverre die Woord nou verkondig word, staan die eskatologiese nou oor elke oomblik van die hede, en in elke sodanige nou word die gerig en lewendmaking voltrek. Maar die lewe wat in hierdie oomblik voltrek word, is geen aanwysbare, voorhandene nie, geen innerlikheid, geen belewenis nie maar die bepaaldheid van die nou deur die woord in soverre dit in die geloof gehoor word, 'sofern also das jeweilige Jetzt verstanden wird als die neue Möglichkeit meines Seins als eines Seinkönnens, als Zukunft habend' (1964c: 147). 
Hieruit blyk duidelik dat die lewe nie vir Johannes sy toekomsverwagting of gerigtheid verloor het nie maar dan juis toekomsgerig en toekomsbepaald is. Die lewe is juis nie ' $n$ toestand nie, geen besit van iets teenwoordigs nie, en nie tydloos nie, 'sondern das als echte Gegenwart aus der Zukunft bestimmte Sein im Augenblick' (1964c: 148). Dit is 'n altyd reeds toekomstig wees. Die hede van die mens is ook geen stilstaande tyd nie. As 'n 'tussen' (Zwischen) word dit of deur die verlede of deur die toekoms bepaal. Of die mens sterf voortdurend saam met sy steeds verdwynende vergangenheid (Vergangenheit), of hy leef uit sy toekoms. Die God van die hede is altyd die komende God, en juis omdat Hy die komende is, is Hy die God van die hede wie se genade die mens van sy gebondenheid aan sy verlede bevry en vir die toekoms - vir God se toekoms - oopmaak (1960a: 90).

Insgelyks het geloof nie die karakter van 'n geestelike of sielige houding nie. Dit is nie die oortuig-wees van ewige waarhede nie en nie die aanvaarding van dogmas nie. 'n Mens kan jou nie daarop beroep dat jy glo nie, jy kan alleen maar telkens weer glo - mag telkens weer glo. Die lewe bestaan juis daaruit dat die mens se klaar-wees, sy afgesluit-wees, ophou en dat hy telkens weer homself as sy moontlikheid teruggegee is. In die geloof word die nou vry van die vergangenheid, van die dood, en word die toekoms oopgemaak. 'Das Leben ist also deshalb Leben, weil es aus der Zukunft her echte Gegenwart ist' (1964c: 148).

Deur die toekomsverwagting te sien as die gelowige se oop-wees vir die toekoms van God as die komende God, het Johannes, so meen Bultmann, die betekenis van die mitologiese verwagtingsbeelde raak geïnterpreteer, want wat hierdie beelde aan die gelowige voorhou, is die oorwinning oor die dood. Die enigste waaromtrent die mens in verband met die toekoms seker is, is die dood. Vir die mens egter wat oop is vir die toekoms as die toekoms van die komende God, het die dood sy verskrikking verloor. Maar hierdie mens sal hom daarvan weerhou om die toekoms wat God in die dood skenk, te probeer beskryf, want alle voorstellings van 'n heerlikheid na die dood kan slegs wensbeelde van die fantasie wees. En om jou van wensbeelde te weerhou, behoort tot die radikale openheid van die geloof vir God se toekoms. Dit beteken dat indien ons wensbeelde vir die toekoms sou fabriseer, ons nie oop is vir die toekoms nie, omdat ons dan juis die toekoms met wensbeelde probeer vooruitloop en vasvang. Uiteindelik is die deur die ontmitologisering vrygestelde betekenis van die mitologiese verwagtingsbeelde 'dass sie von der Zukunft Gottes reden als von der Erfüllung des menschlichen Lebens' (1964c: 90). 


\section{DIE ONTWIKKEI ING NA PAULUS}

Die vraag is nou hoe die kerk na Paulus die probleem van die uitbly van die paroesie hanteer het, wat ook neerkom op die vraag na hoe die kerk die verhouding geskiedenis en eskatologie gesien het. Volgens Bultmann is die antwoord hierop dat toe die insig en oortuiging dat die toekoms die hede op so 'n wyse kwalifiseer dat die gelowige reeds nou eskatologies eksisteer, verlore gegaan het, die verstaan van die paradoks van die Christelike situasie algaande dermate verander het dat die kerk van 'n heilsgemeenskap tot 'n heilsinstelling geword het. Die transendensiekarakter van die kerk is toe nie meer as suiwere toekomsbetrokkenheid verstaan nie maar as die kerk se huidige besit van institute wat transendente kragte reeds meedeel, institute soos die sakramentele kultus en die priesterlike amp. Die kerk het 'aus einer eschatologischen Gemeinde zu einer Kultgemeinde' geword (1964b: 60). Waar die gedagte van die toekomsbetrokkenheid wel nog bly voortbestaan het, is dit minder gekoppel aan die voleinding van die heilsgeskiedenis en die verandering van die wêreld by die aanbreek van die nuwe aion en meer gekoppel aan die toekomstige lewe van die individu anderkant die dood (1968b: 464-466).

Op nog ' $n$ ander wyse is die betrokkenheid op die toekoms gemodifiseer. Hoewel die eskatologiese verwagting nie prysgegee is nie (dit sou volgens Bultmann die prysgawe van die hele Christelike tradisie beteken het), is die vervulling van die verwagting vooruitgeskuif na 'n onbepaalde, ver-liggende tyd (1960b: 97; 1964b: 5859; 1968b: 467). En hoewel hierdie tyd nie meer in die nabye toekoms verwag is nie, is nogtans geglo dat dit onverwags sou kom. Ook die gedagte van die 'tussentyd' het 'n verandering ondergaan. Waar Paulus nog nagewerk het, kom die saaklike, eksistensiale sin van die 'tussen' nog wel tot gelding: radikaal by Ignatius en met 'n sekere krag ook by Kolossense, Efesiërs en 1 Petrus, swakker by die Pastorale Briewe, en selfs nog by die Barnabasbrief, hoewel hy nie deur Paulus beïnvloed is nie. Dit blyk nogtans dat in van hierdie kringe, mense gewoond begin raak het aan wag, ' $n$ ingesteldheid wat by die Pastorale Briewe gelei het tot die ontstaan van die gedagte van Christelike burgerskap. In sekere gevalle, so Lukas-Handelinge, is die tyd na Christus wel as 'n nuwe tyd verstaan, maar dan in kronologiese en nie in saaklike sin nie, as 'n tyd van 'n nuwe kans vir die mens om sy heil na te streef. In sommige vroeg-katolieke geskrifte ontbreek die tussentydgedagte egter geheel en al. Hier word die hede nie meer as 'n geheel nuwe tyd teenoor die verlede verstaan nie maar as ' $n$ tyd van voorlopigheid en voorbereiding - net soos by die Jodedom van die Nuwe-Testamentiese tyd. So het dit gebeur by Hebreërs, Jakobus, 1 Klemens, Didache en die Pastor van Hermas (kyk 1964b: 57; 1968b: 548-549).

Hoe meer die kronologiese verstaan van die 'tussen' na vore getree het, hoe meer is die teenwoordigheid van die heil slegs daarin gesien dat die sondeskuld van 
die verlede deur die in die doop toegeëiende heilswerk van Christus gedelg is en dat daardeur aan die hede die moontlikheid van 'n nuwe aanvang gegee is. Nou kan die mens in gehoorsaamheid aan die wil van God voldoen en goeie werke doen om die toekomstige heil te verwerf. Sodoende is die heil verkort en gereduseer tot slegs die vergewing van gedane sondes. En so is die mens weer aangewys op sy eie krag, en dring perfeksionisme en 'n heiligheidsideaal na vore. Nou kom ook die gedagte van boetedoening na vore. Klein sondes kan direk vergewing voor gevra word, terwyl groot sondes deur die kerk vergewe kan word na boetedoening. Die boetesakrament ontstaan. Geloof is ook nie meer, soos by Paulus en Johannes, 'n nuwe verhouding met God nie maar 'n vertroue op God; vertrouende hoop en volhardende vertroue. Die Pauliniese antitese geloof - werke gaan verlore, die geloofsbegrip verloor sy krag en die begrip vryheid kom kwalik meer voor (1964b: 58). Gehoorsaamheid is nie meer die vanselfsprekende vrug van die geskenkte heil, regverdiging en vryheid nie, maar 'n werk (Leistung) wat die toekomstige heil moet verseker (1960b: 104; 1964b: 57, 62; 1968b: 549).

In hierdie veranderde beskouing het sakramentalisme sterk na vore getree. Dit het ten gevolg gehad dat (a) belangstelling in universele eskatologie plek gemaak het vir die individuele sieleheil, die onsterflikheid bewerk deur die sakrament

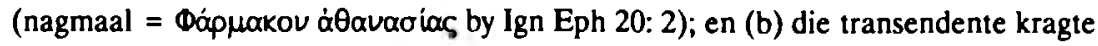
as reeds werksaam in die sakramente gesien is (1964b: 59). Deurdat die jong Christendom van 'n eskatologiese tot 'n kultusgemeente geword het, is die teenwoordigheid van die heil nie meer, soos by Paulus en Johannes, dialekties nie maar reëel gesien as antisipasie van die toekoms. Tot die kultus behoort nou die prediking van die Woord van die waarheid en in die prediking is die heil reeds teenwoordig (Kol 1: 5, 25v; 4: 3; Ef 1: 13; 3: 1vv; 6: 19; 2 Tim 1: 10; Tit 1: 3). Die kerk is nou sakramentskerk, die sfeer waarin die onverganklikheid werksaam is. In die sakramentsviering gebeur die eskatologiese gebeure. Ook die amp wat die sakrament bedien, kry sakramentele karakter deur middel van die ordening. Ampsdraers word priesters in onderskeiding van die gemeentelede as leke. Die Gees is ook nie meer 'n vry werkende krag nie, maar raak aan die amp gebonde, werk alleen deur die amp (1964b: 61-62).

In die sakramentele kerk is die eskatologie wel nie prysgegee nie maar geneutraliseer omdat geglo is dat die toekomstige kragte reeds in die kerk werksaam is. Hierby is die kosmiese eindgebeure as reeds gebeur beskou (1964b: 62). Christus het reeds oorwin met sy hemelvaart (1 Pet 3: 22; 1 Tim 3: 16; 1964b: 63). Hoewel nog verwag is dat Christus eendag as regter oor lewendes en dooies sou terugkeer (1 Pet 4: 5; Pol Ep 2: 1), is die swaartepunt tog verskuif. Dit kan 'n mens daarin sien dat die terme érıф́ंvela en rapovoí wat vroeër gebruik is vir Christus se toekomstige 
verskyning, nou gebruik word vir sy historiese verskyning (2 Tim 1: 10; Ign Fld 9: 2). Die kerk word nou ook gesien as 'n eskatologies-kosmiese gebeure (Kol; Ef), en algou word aan die kerk selfs preëksistensie toegeskryf (Ef 5: 32; $2 \mathrm{Kl} \mathrm{14,} \mathrm{Herm} \mathrm{Vis}$ II, 4: 1).

\section{DIE SEKULARISERING VAN DIE ESKATOLOGIE}

'n Verdere gevolg van die uitbly van die paroesie en van die feit dat die kerk hom as 'n historiese entiteit in die wêreld moes vestig, was die ontstaan van 'n interesse vir die geskiedenis van die kerk. Met ander woorde, toe die kerk homself nie meer verstaan het as die eskatologiese gemeenskap nie, wat hoewel in die wèreld nogtans nie van die wèreld was nie, het die geskiedenis vir hom belangrik begin word. Toe die vroegste kerk homself nog as die eskatologiese gemeenskap gesien het, kon daar nie sprake wees van die geskiedenis van die kerk of kerklike geskiedskrywing nie.

Das neue Gottesvolk, die Kirche, hat keine Geschichte, sie ist ja die Gemeinde der Endzeit, ein eschatologisches Phänomen (1964b: 41).

... sie ist kein historisches Phänomen im Sinne der Weltgeschichte, sie ist aber ein geschichtliches Phänomen in dem Sinne, dass sie sich in der Geschichte verwirklicht (1960c: 48).

Uit laasgenoemde stelling van Bultmann kom iets na vore van die bekende onderskeid wat hy in aansluiting by Kăhler maak tussen historisch en geschichtlich. Eersgenoemde verwys na die historiese gebeure van die verlede wat by wyse van historiese navorsing vasgestel kan word, terwyl laasgenoemde verwys na die betekenis van daardie gebeure vir die mens wat daarmee in ontmoeting tree. Streng gesproke kan die mens die geskiedenis nie soos die natuur bestudeer nie, aangesien hy self deel van die geskiedenis is en in ontmoeting met die geskiedenis tree. Die mens sê naamlik met elke woord oor die geskiedenis in gewisser Weise zugleich etwas über sich selbst' (1958: 7; kyk ook Malet 1969: 61-80; Young 1969: 22-26; Thiselton 1980: 214-215; 241-251; Vorster 1987: 151). Hierdie genoemde onderskeiding word seker op sy beste geïllustreer met die kruisgebeure as voorbeeld: die kruisiging van Jesus is historisch ('n historiese feit van die verlede), terwyl die kruis van Christus geschichtlich is, dit wil sê dit venwys na die betekenis wat die kruisiging van Jesus vir die geloof het. Hierdie Geschichtlichkeit is nie vir 'objektiewe' historiese navorsing waarneembaar nie. Dit kan alleen waargeneem word deur die geloof in of die ontmoeting met die betekenis van die kruis (kyk 1960c: 41-43). 
Terwyl met kerklike geskiedskrywing al 'n begin gemaak is deur die outeur van Handelinge, was Eusebius die eerste wat hom ernstig hieraan gewy het. En nie alleen word die geskiedenis van die kerk geskryf nie, die geskiedenis van die kerk word nou ook in die raamwerk van die wêreldgeskiedenis ingevoeg. Hierdie ontwikkeling het op sy beurt gelei tot die vraag na die sin van die geskiedenis, 'n vraag wat in wese spruit uit die oortuiging gebaseer op die deur die eskatologie bepaalde Joods-Christelike geskiedsbeskouing, naamlik dat die einde van die geskiedenis geken kan word (1964b: 135). Alles sou dan ook, na hierdie oortuiging, volgens 'n goddelike plan verloop het. Die geskiedenis het hiervolgens 'n bepaalde sin en teleologiese verloop: dit ontwikkel na 'n hoogtepunt toe. Hierdie beskouing oor die geskiedenis het egter nie net by Christelik georiënteerde geskiedsfilosowe voorgekom nie maar ook my Marx, hoewel Marx nie soos Hegel die ontvouing van die absolute gees daarin werksaam gesien het nie, maar die dialektiek van die materie (1964b: 65-83).

Waarop dit alles neergekom het, is dat die eskatologie gesekuraliseer geraak het. Met ander woorde, gedra deur die sogenaamde vooruitgangsgeloof (Fortschritsglaube), het die gedagte na vore getree dat die eskatologiese hoogtepunt deur die ontwikkeling van die geskiedenis heen bereik sal word. Hoewel daar deur mense soos Burckhardt, Kierkegaard, Nietzsche, Dostojewski, Tolstoi, Vico, Spengler en Toynbee sterk kritiek uitgespreek is teen hierdie vooruitgangsgeloof, kultuuroptimisme en oortuiging dat daar sin in die geskiedenis is, het hierdie oortuiging by baie tot vandag toe tog bly voortbestaan (kyk 1964b: 84-101).

\section{DIE VERHOUDING GESKIEDENIS EN ESKATOLOGIE}

Maar die vraag na die sin van die geskiedenis het volgens Bultmann 'n sinlose vraag geword, om die eenvoudige rede dat ons nie die sin van die geskiedenis kan ken nie (1964b: 135). Ons kan nie die sin van die geskiedenis bepaal nie omdat ons nie aan die einde van die geskiedenis terugskouend, of buite die geskiedenis oorskouend kan staan nie (1964b: 164; kyk ook 1965a: 102). Daar bly wel die vraag oor na die sin van individuele historiese fenomene en individuele historiese epogge. Maar die sin daarvan kan telkens eers in die toekoms bepaal word.

Es lässt sich sagen: $z u$ jedem historischen Phänomen gehört seine Zukunft, eine Zukunft, in der es erst als das erscheint, was es wirklich ist; genaugenommen muss es heissen: eine Zukunft, in der es immer deutlicher als das erscheint, was es wirklich ist (1964b: 135). 
Wanneer ons dus vra na die betekenis wat historiese fenomene gehad het vir tye of sake wat daarna gekom het, dan eers begin hierdie fenomene om hulle betekenis te onthul. Hulle begin omdat objektiwiteit in historiese kenning nie beskikbaar is in die sin van 'n absolute, finale kennis nie (1964b: 136). Dit beteken dat hierdie fenomene hulle eintlike wese eers dan volledig sal openbaar wanneer die geskiedenis sy einde bereik het. Daar kan in elk geval ook nie 'n vraag na die sin van die geskiedenis gevra word as daarmee bedoel word die vraag na die doel van die geskiedenis nie. Die sin van die geskiedenis is immanent aan die geskiedenis en daarom kan in aansluiting by Croce gesê word 'dass jedes Jetzt ein eschatologisches Jetzt ist und dass Geschichte und Eschatologie identisch sind' (1964b: 161). Die sin van die geskiedenis lê dus in die hede en moet telkens in en vir die hede bepaal word. Deurdat die mens die verantwoordelikheid waarin hy nou gestel is, begryp, begryp hy die sin van die geskiedenis (1965a: 102-103). Dit kom nie neer op 'n atomisering van die geskiedenis nie, want die verantwoordelikheid vir die hede is altyd 'n verantwoordelikheid vir die erfenis van die verlede met die oog op die toekoms. Hoe groter die verantwoordelikheid van die mens is, hoe meer het hy kennis van die verlede nodig (1965a: 103).

Geskiedenisnavorsing dien die menslike selfkennis en selfkennis is niks anders nie as die bewuswees van die verantwoordelikheid vir die toekoms. 'Und ist der Akt der Selbsterkenntnis nicht zugleich ein Akt der Entscheidung?' (1964b: 162). Indien dit korrek is, dan beteken dit dat die historisiteit (Geschichtlichkeit) van die menslike syn eers volledig verstaan is as die menslike syn verstaan is as lewe in beslissing. Geschichtlichkeit is egter nie 'n vanselfsprekende, natuurlike eienskap van die individu nie maar 'n moontlikheid wat aangegryp en verwerklik moet word. Hierby is die lewe van die mens 'n steeds op die toekoms gerigte lewe. Die mens is nooit by sy doel nie. Hy is altyd onderweg, altyd op iets gerig, deur geen hede bevredig nie. Dit beteken dat die eintlike lewe van die mens steeds voor hom staan, dat dit steeds aangegryp, verwerklik moet word. Elke hede word deur sy toekoms bevraagteken en tot verantwoording geroep (1964b: 167; vgl ook 1964c: 145). Die mens se toekomstigheid is die historisiteit van sy bestaan, sy tydelikheid waarin sy historisiteit gegrond is. Die mens is altyd onderweg na wat hy eintlik wil wees. Hierdie eintlikheid (Eigentlichkeit) kan hy verloor of wen. Dit wat hy nastreef, is egter tegelyk 'n verantwoordelikheid (Gefordertes). Dit beteken dat 'sein Wollen zugleich ein Sollen ist' (1964b: 168).

Die mens wat sy historitiseit (Geschichtlichkeit) radikaal verstaan, dit wil sê homself radikaal as die toekomstige verstaan, moet weet dat sy eintlike, outentieke hom alleen as geskenk deur die toekoms gebring kan word. Hy eksisteer uit die toekoms omdat sy geloof en sy vryheid nie 'n besit kan word nie: '... als 
eschatologisches Geschehen können sie ja nicht zu Tatsachen der Vergangenheit werden, sondern sind nur immer als Ereignis wirklich' (1964b: 181). In die grond van die saak bied die toekoms die mens steeds die geskenk van sy vryheid aan. Christelike geloof is die krag om hierdie geskenk telkens aan te gryp. Fakties lewe die mens egter met die strewe om oor die toekoms te beskik - wat hy natuurlik nie kan nie. En dit is juis sy historisiteit wat hom daartoe verlei, omdat sy historisiteit sy verantwoordelikheid vir die toekoms beteken. Sy verantwoordelikheid wek by hom die waan dat hy oor die toekoms kan beskik. In hierdie waan bly hy egter steeds die oue, die deur sy verlede gedetermineerde mens. Hy verstaan nie dat net iemand wat vry is, werklik die verantwoordelikheid kan oorneem nie, en dat 'n mens jou ook nie kan verlaat op 'n moraalwet wat die gewig van die verantwoordelikheid oorneem en verlig nie (1964b: 179).

Dit is duidelik dat wanneer Bultmann van God se toekoms en van die gelowige se oop-wees vir hierdie toekoms praat, hy nie dink aan een of ander datum wat nog in die toekoms moet aanbreek nie (so tereg Ashcraft 1972: 95). Om oop te wees vir God se toekoms beteken om oop en gereed te wees vir enige 'nog nie' waartoe God jou mag roep. Hoewel hy ook praat van die toekoms wat God in die dood skenk, maak hy opvallend nie onderskeid tussen 'n toekoms wat hier en nou voor die gelowige staan en 'n toekoms na die dood nie. Dit gaan dus vir hom, hoewel hy terdeë daarvan bewus is dat die dood 'n einde aan die eksistensie in hierdie wêreld sal bring, gewoon oor die toekoms en toekomstigheid, sonder dat hy spekuleer oor wat die toekoms in die dood sal oplewer. Ook in hierdie opsig beskik alleen God oor die toekoms en nie die mens nie.

In Jesus Christus as die eskatologiese gebeurtenis (Ereignis) het God 'n einde aan die ou wêreld gemaak. In die verkondiging wil die eskatologiese gebeurtenis telkens hede word, en in die geloof word dit telkens gebeurtenis. Vir die gelowige is die ou wêreld op 'n end omdat hy die nuwe mens geword het, 'n vry mens. 'Die eschatologische Existenz ist für den Menschen also dadurch zur Möglichkeit geworden, dass Gott gehandelt und der Welt als 'dieser Welt' ein Ende gemacht hat, indem er den Menschen selbst neu machte ...' (1960c: 39). Die paradoksale van die Christelike verkondiging, respektiewelik die Christelike geloof, is dat die eskatologiese gebeure nie reg verstaan word as dit gesien word as die katastrofale kosmiese einde van die sigbare wêreld nie, maar wel as 'n gebeurtenis binne die geskiedenis wat by Jesus Christus begin het en hom verder voltrek in die loop van die geskiedenis (1964b: 180v). Dit gaan hier egter nie om 'n histories vasstelbare ontwikkeling nie maar om iets wat telkens gebeurtenis word in verkondiging en geloof. Jesus Christus is eskatologiese gebeurtenis, nie as 'n feit van die verlede nie maar as die telkens hier en nou in die verkondiging aansprekende. Die verkondiging vereis as aan- 
spraak beslissing. Maar dit is ' $n$ ander beslissing as die wat ek in verantwoordelikheid oor die toekoms moet neem. In die beslissing van die geloof beslis ek nie vir 'n verantwoordelike daad nie, maar vir 'n nuwe verstaan van myself as een wat deur God se genade van myself bevry en 'n nuut gegewe mens is, en daarmee vir 'n lewe uit die genade van God. Hiermee beslis ek egter tegelyk vir 'n nuwe verstaan van al my verantwoordelike dade, en wel só dat al my beslissinge, al my verantwoordelike doen en late deur die liefde gedra word. Hierdie volledige syn vir die ander is net vir die moontlik wat van hulleself vry geword het. Hierdie vryheid van jouself realiseer sigself steeds in die vryheid van die geschichtliche beslissing.

Die eskatologiese karakter van die Christelike eksistensie kan (ook) as die Godseunskap van die gelowige bestempel word. Hierdie seunskap is nie 'n habitus of 'n eienskap nie maar moet in die beslissing van die teenswoordige lewe telkens weer aangegryp word. 'Jeder Augenblick hat die Möglichkeit, ein eschatologischer Augenblick zu sein, und im christlichen Glauben ist diese Möglichkeit verwirklicht' (1964b: 183; my beklemtoning; kyk ook 1964c: 147). Ons moet hierdie moontlikheid wat daar in elke oomblik sluimer, wakkermaak. Elke oomblik is vir die mens van die uiterste belang: 'Denn das Sein im Augenblick ist sein eigentliches Sein' (1960d: 30). Dit is die oomblik van self-verstaan waartoe die Woord hom wil bring, en as hy in die geloof tot hierdie self-verstaan gebring is, eksisteer hy eigentlich, eksisteer hy eskatologies. In die geloof het die gelowige dan 'n posisie (Standpunkt) anderkant die geskiedenis ingeneem, maar nie as iemand wat aan die geskiedenis ontneem is nie. 'Die Paradoxie der christlichen Existenz ist die, dass der Glaubende der Welt entnommen ist, als gleichsam Entweltlichtes existiert, und dass er zugleich innerhalb der Welt, innerhalb seiner Geschichtlichkeit bleibt' (1964b: 181). Hiermee is die dialektiek van die menslike syn as historiese (geschichtliche) eksistensie aan die lig gebring. Daar kan nou nie meer van so iets as heilsgeskiedenis sprake wees nie, alleen maar van profane geskiedenis. En die feit dat die geskiedenis van die gelowige anderkant die wèreldgeskiedenis lê, maak dat sy geskiedenis nie langer meer as funksie van die wêreldgeskiedenis verstaan kan word nie (1960b: 106).

\section{EVALUASIE}

Dit het uit hierdie oorsig oor Bultmann se ontmitologisering van die Nuwe-Testamentiese eskatologie weer eens duidelik geword watter rol by hom gespeel is deur Heidegger se eksistensiale analise van Dasein en deur die, volgens Bultmann, in die Nuwe Testament ontdekte Geschichtlichkeit des Daseins, soos dit deur die filosofie getipeer is (1960c: 32). Dit het verder duidelik geword dat hy hom volkome vereen- 
selwig het met Johannes se verstaan van die eskatologie, iets waarvan hy die aanloop reeds by Jesus en Paulus bespeur het. Heidegger se analise van Dasein formuleer hy soos volg:

... der Mensch, geschichtlich existierend in der Sorge um sich selbst auf dem Grunde der Angst, jeweils im Augenblick der Entscheidung zwischen der Vergangenheit und der Zukunft, ob er sich verlieren will an die Welt des Vorhandenen, des 'man', oder ob er seine Eigentlichkeit gewinnen wil in der Preisgabe aller Sicherungen und in der rückhaltlosen Freigabe für die Zukunft (1960c: 33)!

Hierdie analise van Dasein is volgens Bultmann bloot die profane, filosofiese daarstelling van wat in die Nuwe Testament onder Dasein verstaan word. Dit wil sê, dit is hoe die Nuwe Testament die mens verstaan en dit is gevolglik waarom dit ook in die grond van die saak in die Nuwe-Testamentiese eskatologie gaan.

Hieruit en uit wat tot dusver uit Bultmann se standpunt geblyk het, word dit duidelik van watter deurslaggewende eksistensiële belang die toekoms en die oomblik vir menslike eksistensie geag word. Die toekoms figureer hier radikaal anders as in die tradisionele denke oor die eskatologie. Dit gaan nie meer om ' $n$ in die toekoms uitstrekkende tydsperiode waarin daar nog uitstaande dinge op bepaalde datums sal plaasvind, met as laaste datum die paroesie en die einde van die wêreld nie. Dit gaan ook nie oor toekomstige feite wat nog tot kennis van die gelowige moet kom of om 'n eindpunt in die geskiedenis waarheen die geskiedenis as hoogtepunt ontwikkel en beweeg nie. Toekoms is hier van ontologiese betekenis. Dit word in saaklike sin verstaan as kwalitatiewe komponent van menslike eksistensie, as die komponent wat menslike eksistensie as toekomstigheid, kwalifiseer. Hierdie toekomstigheid van die mens is enersyds sy ontologiese toekomsgerigtheid, sy oop-wees vir die toekoms en sy vry-wees van homself en vir die toekoms, en andersyds sy bepaal-wees deur die toekoms. Hoewel die filosofie waarby Bultmann aansluiting gevind het, natuurlik ook van toekoms in hierdie terme praat, kan daar vir hom in hierdie verband net van één toekoms sprake wees: die toekoms van God. Wat die filosofie oor menslike eksistensie en die toekoms gesê het, is eintlik nie 'n vinding van die filosofie nie. Wat die filosofie raakgesien het, is reeds deur die Nuwe Testament gesê (1960c: 33). Dit sluit die ontologiese feit in dass der Mensch immer nur das sein und werden kann, was er schon ist (1960c: 36). En in eskatologiese terme beteken dit dat die eskatologiese eksistensie deurgevoer kan word omdat toe die tyd vervul is, God sy Seun gestuur het om die mens uit die teenswoordige bose wêreld te bevry (Gal $4: 4 ; 1: 4)$. Hierdie vry-wees van jouself en van 
die wêreld en hierdie oop-wees vir die toekoms is egter alleen moontlik deur geloof, en hierdie geloof kan alleen moontlik wees as geloof in die liefde van God wat in Jesus Christus geopenbaar is (1960c: 39). Anders as die filosofie, kan die Nuwe Testament dus nie van die mens as sodanig sê dat hy reeds is wat hy kan word nie. Die Nuwe Testament sê dit alleen van die gelowige wat die bevrydende daad van God aan hom laat voltrek het (1960c: 36).

Maar hierdie toekoms ontmoet 'n mens alleen in die oomblik, hier en nou, en dit maak die oomblik, elke oomblik, van die uiterste eksistensiële belang. Dit is telkens en slegs in die oomblik tussen verlede en toekoms dat beslis word en kan word vir outentieke of nie-outentieke eksistensie. Dit is slegs in die oomblik dat die mens eksisteer en dat hy eskatologies kan eksisteer. Om Bultmann weer in hierdie verband aan te haal: 'Denn das Sein im Augenblick ist sein eigentliches Sein' (1960a: 30). Dit is slegs die oomblik wat tot die mens se beskikking is; hy beskik nie meer oor die verlede nie en nog nie oor die toekoms nie. Die toekoms sal eers tot sy beskikking wees in daardie oomblik(ke) wat hom telkens uit die toekoms as hede aangebied sal word. Die beslissings wat telkens hier en nou in die oomblik geneem word, het natuurlik konsekwensies vir die toekoms, maar wat die konsekwensies daarvan sal wees, sal ook telkens weer slegs in die toekomstige oomblikke van beslissing bepaal kan word. Toekomstige beslissings kan nog altyd weer verloor wat deur huidige beslissings gewen is, en andersom.

Omdat elke oomblik die moontlikheid het om 'n eskatologiese oomblik te wees en inderdaad deur die geloof tot 'n eskatologiese oomblik word, is fantasiebeelde oor die toekoms nie net sinloos nie, maar ook nie ter sake nie. As die oomblik vir die mens (gelowige) tot eskatologiese oomblik geword het, beteken dit dat hy tot sy nuwe selfverstaan gekom het en dus outentiek eksisteer, eskatologies eksisteer. Outentieke, en derhalwe eskatologiese eksistensie, het niks nodig wat daar nog moet bykom nie, nie fantasiebeelde oor die toekoms nie en ook nie nog uitstaande gebeure wat op uitstaande datums sal plaasvind nie. Eskatologiese eksistensie kan reeds hier en nou verwerklik word en word, soos reeds gesê, inderdaad deur die geloof verwerklik. In hierdie verband moet egter met klem herhaal word dat hieruit nie toekomsloosheid afgelei moet word nie. Inteendeel, Bultmann wil hiermee juis die eksistensiële betekenis van die toekoms op sy kragtigste tot gelding laat kom. Bultmann kan ewe min daarvan beskuldig word dat hy hiermee die eskatologie onteskatologiseer het (teen Du Plessis 1970: 141). Daar kan miskien wel in 'n sekere sin van 'punktuele' eskatologie by hom gepraat word (so Cullmann 1967: 23), maar dan beslis nie van 'n 'punktuele' sonder toekomsbepaaldheid nie. Van egte hede kan daar trouens vir hom alleen sprake wees waar daar sprake is van 'n uit die toekoms bepaalde syn in die oomblik (kyk weer 1964c: 148). Soos ons reeds hierbo 
gesien het, is die mens radikaal toekomstig omdat hy deur geen hede bevredig is nie, nooit by sy doel is nie, en dat sy eintlike lewe steeds voor hom staan en steeds aangegryp en verwerklik moet word. Wat hierby as van die uiterste belang beskou moet word, is Bultmann se oortuiging dat die mens se eintlike self hom alleen as geskenk deur die toekoms gebring kan word, dat die toekoms hom steeds die geskenk van sy vryheid aanbied. Hy moet dit slegs deur geloof tot sy eie maak.

Ewe belangrik is die feit dat Bultmann hierdie eskatologiese eksistensie van die gelowige ook as entweltlichte Existenz beskryf. Dit maak geloofseksistensie onafhanklik van die verloop van die geskiedenis, al eksisteer die gelowige paradoksaal nog in hierdie wêreld en as deel van die geskiedenis. Natuurlik is Bultmann nie daarvoor blind dat die geskiedenis en omgewingsomstandighede 'n uitwerking op die mens het nie. Hoe die mens hom hierdeur laat beïnvloed of hoe hy hierop reageer, bly nietemin sy verantwoordelikheid om oor te beslis in elke oomblik waarin hy steeds moet kies vir outentieke of nie-outentieke eksistensie. Met die moontlikheid wat hom aangebied word om vry te word van alles wat outentieke eksistensie in die weg staan, kan hy sy vryheid van die geskiedenis en die wêreld steeds deur die geloof verwerklik, kan hy die wêreld oorwin. Selfs in die gevalle waar die mens moet verdra of verduur, kan met reg gesê word 'dass die Reactio eine spezifische Art der Actio ist, dass das Leiden nicht eine rein passive Haltung ist, sondern Aktivität als Ertragen, als Geduld, und dass es deshalb als Erweis des Willens zur Geschichtlichkeit gehört (1964b: 170).

Dat Bultmann se ontmitologisering van die Nuwe-Testamentiese eskatologie ingrypende gevolge vir die tradisionele Christelike verstaan van die eskatologie inhou, het geen argumentvoering nodig nie. Die voor die hand liggendste hiervan is sonder twyfel die feit dat hy as 't ware 'n 'verskuiwing' van die eskatologiese verwagting laat plaasvind het: vanaf die tradisionele eind-verwagting na 'n verwagting wat op die hede gerig is, op die eskatologiese Jetzt, waarin outentieke eksistensie, en daarom eskatologiese eksistensie, nou reeds realiseer. Indien Bultmann, in sy ontmitologisering van die Nuwe-Testamentiese eskatologie, wat basies die onthistorisering en ontapokaliptisering daarvan is, gelyk gegee word, moet aanvaar word dat hiermee saam 'n hele aantal Christelike geloofsinhoude en konsepte wat met die tradisionele eind-verwagtingskonsep saamhang, prysgegee en met ander vervang sal moet word. Die belangrikste gevolge wat dit inhou, is die volgende:

- Dat 'n mens jou nie meer God as 'n daarbo in die hemel voorhande wese kan voorstel nie, en die 'hemel' in die ou sin van die woord nie meer vir jou kan bestaan nie. 
- Dat so min as wat Christus na die hemel toe opgevaar het, so min sal Hy (weer) op die wolke van die hemel kom om die gelowiges mee te voer na die hemel toe, waar hulle vir ewig sal voortlewe.

- Dat Christus daarom nie eers aan die einde van die tyd sal kom nie, maar telkens hier en nou kom in die Woord wat Hom verkondig.

- Dat die Gees, geontmitologiseer en eksistensiaal geïnterpreteer, enersyds saam met Johannes gesien moet word as Christus self wat deur die woordverkondiging na sy gemeente toe kom en telkens weer kom, en andersyds saam met Paulus gesien moet word as in die grond van die saak 'die im Glauben erschlossene faktische Möglichkeit eines neuen Lebens' (1960c: 31).

- Dat die kerk nie meer as 'n historiese nie maar as 'n eskatologiese fenomeen gesien moet word, 'n fenomeen bestaande uit heiliges, dit wil sê 'in die eschatologische Existenz Versetzten' (1960c: 47), 'n fenomeen wat geen geskiedenis het nie maar wat hom in die geskiedenis verwerklik.

- Dat die allerhoogste premie op die woordverkondiging geplaas moet word omdat Christus as die gekruisigde en opgestane Hom slegs in die Woordverkondiging laat ontmoet, nêrens anders nie.

- Dat die Woordverkondiging self tot die eskatologiese heilsgebeure behoort deurdat daarin die kruis en opstanding van Christus hede word en die eskatologiese Jetzt gebeur.

- Dat die gelowige nie eers aan die einde van die geskiedenis liggaamlik/histories in hierdie wêreld sal opstaan nie (so min as wat Christus liggaamlik/histories opgestaan het), maar nou reeds wanneer hy die opgestane Christus in die Woordverkondiging ontmoet en deur die geloof saam met Hom gekruisig word en saam met Hom opstaan.

- Dat 'n mens jou ook nie meer so iets as 'n hel onder hierdie aarde kan voorstel waarheen die goddelose veroordeel sal word nie, net so min as wat Christus na die hel toe neergedaal het.

- Dat die gerig nie eers aan die einde van die tyd sal plaasvind nie maar reeds plaasgevind het met die koms van Jesus Christus en met die nie-aanvaarding van die Woord wat Hom verkondig.

- Dat lewe in geloof in die openbaring dieselfde is as om in die hemel te wees, terwyl lewe sonder geloof in die openbaring voortaan die hel is.

* Dat die geloof nie die aanvaarding is van algemene, tydlose waarhede of die virwaar-hou van geloofsproposisies of 'n sielige houding nie, maar die kom tot selfverstaan, tot eskatologiese en daarom entweltlichte eksistensie.

* Dat hoop as niks anders gesien moet word as openheid vir die toekoms nie. 
- Dat die vervulling van die mens se lewe nie aan die einde van die wêreld of die geskiedenis lê nie maar in die toekoms van God; God wat die God van die toekoms is as die teenwoordige God.

- Dat God reeds 'n einde aan die wêreld as 'hierdie wêreld' gemaak het, deurdat Hy die mens nuut gemaak het.

$\mathrm{Na}$ alles wat tot dusver gesê is, kom die vraag nou onwillekeurig na vore of Bultmann reg laat geskied het aan die eskatologie van die Nuwe Testament. Of anders gestel, sou die eksponente van die verskillende Nuwe-Testamentiese verwagtingsbeelde Bultmann gelyk kon gee dat dit inderdaad is wat hulle met hulle eskatologiese voorstellings tot uitdrukking wou bring? In die eerste plek, sou hulle en ons nie moet saamstem dat Bultmann op illegitieme wyse moderne filosofiese denkkategorieë op die Nuwe Testament afgeforseer het en daarmee die 'realistiese' Nuwe-Testamentiese verwagtings totaal nek omgedraai het nie? Ons is bewus daarvan dat dit onder andere ' $n$ beswaar is wat kritici teen Bultmann inbring. Boers (1976: 63) byvoorbeeld, argumenteer dat 'n ontmitologiserende of onthistoriserende interpretasie van die Pauliniese eskatologie, onvermydelik iets van die Pauliniese verkondiging laat verlore gaan. Hoewel Boers toegee dat Paulus dit oor die opstanding van Jesus Christus en oor sy paroesie mis gehad het, is hy nogtans van oordeel dat Paulus vir ons verlore gaan as ons probeer om sy boodskap vir ons tyd te laat spreek. 'All that is left is to let him return to his own time and see if we can learn from him without forgetting the difference between his time and ours' (Boers 1967: 64). Hoe 'n mens moet sien wat jy van Paulus kan leer, sê Boers egter nie. Bultmann daarenteen het minstens probeer om van Paulus iets te maak. Of hy Paulus of die res van die Nuwe Testament daardeur verloor het, is 'n vraag. ' $n$ Mens moet jou afvra wat bereik word wanneer 'n mens Paulus na sy eie tyd laat terugkeer en hom sodoende 'behou', maar vir die mens van vandag niks wen nie.

'n Mens kan verder vra of Bultmann hom doelbewus blind gehou het vir die dubbele tydelike polariteit van die 'reeds' en die 'nog nie' wat volgens Thiselton (1980: 265) deur so baie erkende Nuwe-Testamentici as kenmerkend van die Nuwe Testament beskou word. En is hy met homself in teenspraak deurdat hy die een oomblik sê dat die Nuwe-Testamentiese eskatologie ontmitologiseer moet word omdat dit mitologies is, en die volgende oomblik sê dat dit gedoen moet word omdat die Nuwe Testament self geontmitologiseer het (Thiselton 1980: 266)? Dit lyk of Thiselton vir Bultmann op hierdie punt doelbewus verkeerd verstaan het. Bultmann sê nèrens dat die Nuwe-Testamentiese eskatologie tegelyk mitologies en geontmitologiseerd is nie. Hy sê juis dat daar 'n ontwikkeling plaasgevind het van mitologies na geontmitologiseerd. 
Voeg hierby die vraag of daar by hom 'n ongerymdheid aanwesig is deurdat hy die Christusgebeure in die historiese verlede as van absolute betekenis beskou vir geloofseksistensie in die hede, maar nie die moontlikheid van 'n historiese eskatologiese gebeure in die toekoms wil aanvaar nie (Young 1969: 143). Dit is inderdaad ' $n$ lastige vraag hierdie. Maar in die lig van die feit dat Bultmann die Christusgebeure in die historiese verlede geschichtlich as dié eskatologiese gebeure verstaan, kan daar nie vir hom histories nog iets toevoegbaar wees by die eksistensiële toeëiening van hierdie gebeure deur die geloof nie. Wat histories verder gebeur, is dus vir hom saaklik irrelevant. Indien dit so sou wees dat die lewe van die gelowige eers aan die einde van die geskiedenis tot volkome vervulling sou kom, sou dit eenvoudig beteken dat hy nie deur werklike geloofsbeslissing tot outentieke eksistensie hier en nou en telkens weer, gekom het nie.

Kom die feit dat Bultmann die tradisioneel Christelike eindverwagting as Zeitlichkeit der Existenz interpreteer, neer op 'n antropologiese verenging wat uiteindelik as resultaat het dat 'Gottes Herrsein über den chronologischen Zeitablauf im gesamten Kosmos und im einzelnen Menschenleben von jener Enge erdrückt wird' (Hohmeier 1964: 125; kyk ook Lohmeyer 1960: 141-142)? Hierop moet geantwoord word dat Bultmann nooit die heerskappy van God oor of sy handelinge in die kosmos of die geskiedenis of die lewe van die mens ontken het nie. Wat hy wel gesê het, is dat hierdie handelinge nie deur objektiewe waarneming vasstelbaar is nie maar alleen in die geloof waargeneem kan word (kyk Pelser 1987: 78-80). Die gelowige kan alleen van die handelinge van God praat wat hom raak, en daarom is hierdie uitsprake tegelyk antropologiese uitsprake. Dit gaan dus nie om 'n antropologiese verenging nie. Dit gaan gewoon om wat die gelowige eksistensieel ervaar. Wat hy nie eksistensieel kan ervaar nie, kan hy hom nie oor uitspreek nie en is nie sy saak nie. Dit is God se saak.

'n Laaste vraag. Is Bultmann nie in teenspraak met homself wanneer hy aan die een kant daarvan uitgaan dat alle wêreldbeelde histories relatief is, maar aan die ander kant die absoluutheidsaanspraak maak dat die eksistensiale interpretasie van die Bybelse teks die enigste korrekte interpretasie is nie? Verabsoluteer hy nie tog ook die sogenaamde moderne, wetenskaplike wêreldbeeld deur dit teenoor die ou mitiese te stel as die wêreldbeeld wat ontmitologisering noodsaaklik en onvermydelik maak nie? Kan hy in die lig van die relatiwiteit van wêreldbeeld werklik beweer dat wie nie eksistensiaal interpreteer nie, alleen 'n mitologiese interpretasie van die Nuwe Testament kan verskaf? Is die eksistensiale interpretasie nie ook maar in 'n sekere sin onderworpe aan die relatiwiteit van Bultmann se wêreldbeeld as vooronderstelling vir sy interpretasie nie (kyk Runzo 1979)? Oordeel hy ten slotte, nie te simplisties en onjuis oor die moderne, 'wetenskaplik' gevormde 
wèreldbeeld en oor moderniteit deurdat hy enersyds veronderstel dat daar in alle sektore van die moderne samelewing én gemeenskaplike wêreldbeeld bestaan, en andersyds veronderstel dat die moderne mens per se nie meer mitologies dink en selfs absurde dinge kan glo nie (Jaspers 1966: 12-13; 18-19; Macquarrie 1969: 230240)?

Dit is sonder twyfel so dat hoewel Bultmann wêreldbeeld as histories beskou, die 'moderne' wêreldbeeld by hom 'n belangrike vooronderstelling is vir ontmitologisering (kyk o a 1960c: 16-21). Dat die moderne wêreldbeeld en 'n moderne eksistensie filosofie egter nie deur hom tot absoluuthede verhef is nie, blyk duidelik uit die feit dat hy van oortuiging is dat ontmitologisering reeds in die Nuwe Testament te midde van 'n mitiese wêreldbeeld voorgekom het, en dat dit juis gebeur het omdat 'n eksistensiale verstaan van Dasein na vore getree het. Dat Bultmann waarskynlik te simplisties en veralgemenend oor die moderne wêreldbeeld gedink het en die moderne mens te onrealisties as nie-mitologies-denkend voorgestel het, is seker waar. Maar dat hy in die ou mitiese wêreldbeeld en in die daarmee samehangende eskatologie, elemente bespeur het wat vir die moderne mens se geloof as onoorkomelike struikelblokke in die pad lê, is ewe waar. Dat hy daarom 'n eerlike poging aangewend het om hierdie struikelblokke uit die weg te help ruim, kan nie betwyfel word nie. Of hy daarin geslaag het, is vir verskeie van sy kritici natuurlik'n vraag of word betwyfel.

Miskien is die grootste probleem wat uiteindelik deur baie met Bultmann se eskatologie ervaar word, die gewaarwording dat die geweldige klem wat hy op die hede en die eksistensie in die hede lê, tog die toekomsperspektief laat vervaag. En dan veral die oortuiging en verwagting dat God nog in die toekoms nuwe dinge sal laat gebeur ongeag die geloofsbeslissings hier en nou. Daar is steeds nie alleen die verwagting van 'n onuitspreeklik wonderlike lewensvervulling aan die einde van die tyd, van die verandering van ongeluk in geluk, droefheid in blydskap, lyding in vreugde, ensovoorts nie, daar is ook die verwagting van die vergelding van liefdeloosheid, onreg, onderdrukking, vyandskap ensovoorts. Dit kom in die grond van die saak daarop neer dat die situasie en die lewe van die hede nie as die eintlike, die ware gesien en beleef word nie maar as die voorlopige wat nog radikaal sal verander en deur die utopiese vervang sal word.

Dat die gelowige so 'n verwagting kan koester, is op grond van Nuwe-Testamentiese verwagtingsbeelde begryplik. Die uiters belangrike vraag is egter wat dit vir die hede inhou. Laat dit die deursneë gelowige voldoende of enigsins erns met sy of haar geloofseksistensie hier en nou maak? Bultmann haal heel tereg met instemming Pascal se stelling aan dat ons nooit heelhartig in die hede leef nie, omdat ons altyd deur ons herinnering die aangename van die verlede probeer vas- 
hou en die toekoms probeer verhaas met die hoop dat dit vir ons geluk sal bring. Sodoende is ons nie op die hede gerig nie en benut ons nie die enigste tyd, die hede, wat werklik tot ons beskikking is nie. Derhalwe leef ons nie, maar hoop ons slegs om te lewe. En omdat ons ons altyd daarop voorberei om gelukkig te wees, is dit onvermydelik dat ons in feite nooit gelukkig is nie (1956: 219-220).

Die wins en die bevrydende van Bultmann se eskatologie is juis hierdie geweldige erns wat hy met die hede maak en met die onontduikbare verantwoordelikheid van eksistensiële beslissing in die oomblik. Dat hy eksistensie hiermee van die verlede en die toekoms losmaak, dit van sy durende karakter ontneem en tot iets wisselvalligs laat word (so Ashcraft 1972: 103), is eenvoudig nie waar nie. Die gewig wat hy hiermee saam aan die verlede maar veral aan die toekoms verleen, laat die oomblik en die eksistensie in die oomblik juis vastigheid kry, laat dit juis nie vervlugtig nie maar tot 'n konkrete geleentheid word. Dit rig 'n ernstige maar ook bevrydende appel tot die kerk, die prediking van die kerk en die geloof van sy lidmate om werklik eksistensieel erns te mak met die pregnansie van die oomblik, wat in die volste sin van die woord eskatologiese oomblik is en as sodanig moet realiseer. Watter uitstaande verwagting sou die gelowige nog kan koester as hy of sy deur die gelowige hoor van die prediking tot 'n nuwe selfverstaan kom, hom of haar saam met Christus laat kruisig en saam met Hom opstaan en so die nuwe mens word wat hy of sy in Christus is? So 'n mens het ware toekoms omdat hy of sy dan waarlik eskatologies eksisteer.

Dit beteken geensins dat die hoop op wat God nog vir die gelowige in die toekoms mag beskik, hiermee by die wortel afgesny is nie. Dit beteken alleen dat hoop as die gelowige se openheid vir die toekoms nie 'n Fernerwartung moet wees nie, maar 'n verwagting van wat God reeds hier en nou en in elke toekomstige oomblik mag beskik en ten opsigte waarvan telkens in daardie oomblik 'n eksistensiële beslissing geneem moet word. Dit geld ook die toekoms wat God in die dood mag skenk, die toekoms waaraan die gelowige nou reeds prolepties deel het en kan hê wanneer hy of sy elke oomblik die beslissing vir outentieke eksistensie, vir lewe, mak, en so reeds anderkant die dood te staan kom. Dit is vir die gelowige genoeg om dit elke oomblik te weet en te belewe. Wat anderkant die dood vir hom of haar beskik sal word, kan hoogstens die verdere bevestiging of die bekroning hiervan wees, maar oor die hoe of die wat daarvan kan 'n mens jou nie uitspreek nie, dit berus by God. 


\section{Literatuurverwysings}

ASHCRAFT, M 1972. Rudolf Bultmann. Waco: Word Books. (Makers of the modern theological mind.)

BOERS, HW 1967. Apocalyptic eschatology in 1 Corinthians 15: An essay in contemporary interpretation. Interp. 21, 50-65.

BULTMANN, R 1949. Das Urchristentum im Rahmen der antiken Religionen. Zürich: Artemis Verlag. (ErasB.)

BULTMANN, R 1956. Marburger Predigten. Tübingen: Mohr.

BULTMANN, R [1926] 1958. Jesus. Tübingen: Mohr.

BULTMANN, R [1933] 1964. Glauben und Verstehen: Gesammelte Aufsäıze, I. 5. Aufl. Tübingen: Mohr.

BULTMANN, R 1960. Glauben und Verstehen: Gesammelte Aufsätze, III. Tübingen: Mohr.

BULTMANN, R 1965. Glauben und Verstehen: Gesammelte Aufsätze, IV. Tübingen: Mohr.

BULTMANN, R [1954] 1960a. Die christliche Hoffnung und das Problem der Entmythologisierung, in Bultmann 1960: 81-90.

BULTMANN, R [1954] 1960b. Geschichte und Eschatologie im Neuen Testament, in Bultmann 1960: 91-106.

BULTMANN, R [1948] 1960c. Neues Testament und Mythologie: Das Problem der Entmythologisierung der neutestamentlichen Verkündiging, in Bartsch, $\mathrm{HW}$ (Hrsg), Kengma und Mythos: Ein theologisches Gespräch, I. Band. 4. Aufl, 15-48. Hamburg: Herbert Reich-evangelischer Verlag. (ThF1.)

BULTMANN, R 1960d. Der Begriff der Offenbarung im Neuen Testament, in Bultmann 1960: 1-34.

BULTMANN, R [1958] 1964a. Jesus Christus und die Mythologie. Hamburg: Furche. (Stundenbuch 47.)

BULTMANN, R [1957] 1964b. Geschichte und Eschatologie. 2. Aufl. Tübingen: Mohr.

BULTMANN, R [1928] 1964c. Die Eschatologie des Johannes Evangeliums, in Bultmann 1964: 134-152.

BULTMANN, R [1962] 1965a. Das Verständnis der Geschichte im Griechentum und im Christentum, in Bultmann 1965: 91-103.

BULTMANN, R 1965b. Zum Problem der Entmythologisierung, in Bartsch, HW (Hrsg), Kerygma und Mythos: Ein theologisches Gespräch, II. Band, 179-190. 2. Aufl. Hamburg: Herbert Reich-evangelischer Verlag. (ThF2.)

BULTMANN, R 1968a. Das Evangelium des Johannes. 10. Aufl. Göttingen: Vandenhoeck. (KEK.) 
BULTMANN, R 1968b. Theologie des Neuen Testaments. 6. Aufl. Tübingen: Mohr. CULLMANN, O 1967. Heil als Geschichte: Heilsgeschichtliche Existenz im Neuen Testament. 2. Aufl. Tübingen: Mohr.

DU PLESSIS, IJ 1970. Die aard en betekenis van die eskatologie in die eksistensieteologie van Bultmann en sy navolgers. Neotestamentica 4, 132-149.

HOHMEIER, F 1964. Das Schriftverständnis in der Theologie Rudolf Bultmanns. Berlin: Lutherisches Verlagshaus. (AGTL XIII.)

JASPERS, K 1966. Wahrheit und Unheil der Bultmannschen Entmythologisierung, in Bartsch, HW (Hrsg), Kerygma und Mythos, III. Band: Das Gespräch mit der Philosophie, 9-46. 4. Aufl. Hamburg: Herbert Reich-evangelischer Verlag. (ThF5.)

KÖRNER, J 1957. Eschatologie und Geschichte: Eine Untersuchung des Begriffes des Eschatologischen in der Theologie Rudolf Bultmanns. Hamburg: Herbert Reichevangelischer Verlag. (ThF13.)

LOHMEYER, E [1948] 1960. Die rechte Interpretation des Mythologischen, in Bartsch, H W (Hrsg), Kerygma und Mythos: Ein theologisches Gespräch, I. Band, 139-149. 4. Aufl. Hamburg: Herbert Reich-evangelischer Verlag. (ThF1.)

MACQUARRIE, J 1969. The scope of demythologizing: Bultmann and his critics. Gloucester: Peter Smith.

MALET, A 1969. The thought of Rudolf Bultmann. Transl by Strachan, R. Schannon: Irish University Press.

PELSER, GMM 1987. Die ontmitologiseringsprogram van Rudolf Bultmann. HTS $43,162-191$.

RUNZO, J 1979. Relativism and absolutism in Bultmann's demythologising hermeneutic. $S J T h$ 32, 401-419.

THISELTON, AC 1980. The two horizons: New Testament hermeneutics and philosophical description with special reference to Heidegger, Bultmann, Gadamer and Wittgenstein. Exeter: Paternoster.

VORSTER, WS 1987. Rudolf Bultmann as historikus. HTS 43, 138-161.

YOUNG, NJ 1969. History and existential theology: The role of history in the thought of Bultmann. Philadelphia: Westminster. 